\title{
INVESTIGATING THE CROWDING OUT EFFECT OF GOVERNMENT EXPENDITURE ON PRIVATE INVESTMENT
}

\section{- Olawunmi Omitogun}

\begin{abstract}
This study investigates the crowding out effect of government expenditure on private investment in Nigeria using annual data spanning from 1981-2015. The research is shaped by the high level of competition that investors are exposed to in the economy. Competitiveness is also supported by government plans to reduce investment burden by increasing expenditure in all strategic sectors of the economy. The present paper adds to the existing literature by investigating the effect of disaggregated government expenditure on private investment in Nigeria. The estimation techniques of the study include pre-and post-estimation, including descriptive statistics, correlation matrix, a unit root test and econometric estimation using the Auto Regressive Distributed Lag (ARDL) method. Government capital expenditures are estimated marginally, while recurrent expenditures are estimated in terms of elasticity, as the variables (recurrent expenditures) show a strict long tail to the right. It was observed in general that the effect of government expenditure on private investment depends on the components of the expenditure. Some were found to crowd out private investment while some crowd in private investment. This implies that not all government expenditure is channeled in such a way that it attracts private investment in the economy. It is therefore recommended that the policymakers should take into consideration the existence of private investors in expenditure plans.
\end{abstract}

Keywords: Recurrent Expenditure, Capital Expenditure, Private Investment, ARDL JEL Classification: $\mathrm{H}_{3}$

Received: March, 2018

1st Revision: June, 2018

Accepted: October, 2018

\section{INTRODUCTION}

In recent years, a major discussion in economics has been taking place concerning the link between government spending and economic performance (Basar \& Temurlenk, 2007). Recently, the challenges faced by the most developed economies in terms of finance and economic instances have been sparked by an increase in public spending (Bom, 2017). Such is also the case in developing countries such as Nigeria (Muhammad et al., 2012). This pattern of expenditure largely determines how private investors are motivated to invest more in the economy. Mahmoudzadeh et al., (2013) and Bom (2017) have confirmed that the fiscal policy of an economy 
determines the existence of investors in such economy.

Studies have argued both in support as well as against increases in government spending. Some see an increase in government spending as a means of increasing economic activities through investment in basic needs (e.g. infrastructure) that attract private investors to invest more in an economy (see Mahmoudzadeh et al., 2013; Basar and Temurlenk (2007) and Nwosa et al., 2013). Some of these studies have also submitted their arguments in support of the neoclassical theory of investment, i.e. that the interest rate is determined by the level of savings, which has a connection to the pattern of expenditure in an economy with the assumption of full employment (Sineviciene \& Railiene, 2015). On the other hand, others have argued from the Keynesian view that government expenditure pattern complements private investments with a low interest rate (Fujii et al., 2013; Ferria \& Voia, 2015; and Sineviciene, 2015). These outlooks are based on the different approaches as well as the time frame used to make conclusions. The majority of the studies used the Vector Auto-regressive

Approach (VAR) and Error Correction Method (ECM) to analyze their findings. Nigeria has been faced several challenges in recent years in terms of its budget status. The country has been running on a budget deficit over several years, during which no option other than to consider internal or external debt to finance the budget was possible. In this process, the question is "Does the pattern of financing or source of spending crowd in or out private investment in line with what the respective theory says?" This study therefore differs from previous ones by investigating the crowding out effect of government expenditure pattern as a fiscal policy tool on private investment using the Auto-regressive Distributed Lag (ARDL) approach based on the nature of the pre-estimation test results covering the period 1981 to 2015. This study is also shaped by the effect that competitiveness government fiscal policy causes among various private investors in the economy. Private investors are challenged to re-strategize in order to remain in the market, as most government policies are tailored towards increasing the number of investors in the economy, which aids competitiveness.

The rest of the paper is divided into four sections. Section two contains the literature review, while the source of data, methodology and model specification is presented in section three; section four presents the analytical framework and discussion of results, with section five devoted to the conclusion and recommendations.

\section{THEORETICAL BACKGROUND}

This section presents a theoretical and empirical understanding of the impact of government expenditure on private investment. Neoclassical theory advocates that an economy attains full employment and an increase in interest rates as its reserve ratio falls. According to this theory, there is either an increase in government expenditure, or investment crowds-out private investment. Contrary to neoclassical thought, Keynesian theory is of the view that an increase in government spending facilitates a complement private investment, and the interest rate impact on investment is very low. In contrary to the neoclassical and the Keynesian approaches, the Ricardian Equivalence hypothesis states that there is no nexus between private investment and government spending pattern. This is because most government spending is a result of revenue 
from tax, and when there is budget deficit, individuals still maintain their levels of consumption, savings and investment behavior in the economy.

On the empirical front, Ho (2001) has confirmed that a significant substitution for private consumption by government is the spending which exists in the OECD countries, i.e. when the presence of real disposable income precludes the permanent income hypothesis for Keynesian expansionary fiscal policy. Sineviciene \& Railiene (2015) have argued from their findings that in EU countries government size and the tax burden cannot be treated as the only detrimental factors for private investment. They contend that economic development is better explained by the differences in private investment level than by government size and the tax burden. Thus, the level of private investment depends on the particular countries' economic development. In Fiji, Narayan (2004) noted that government investment crowded in private investment from 1950 to 1975, while between 1976 and 2001, there was a weak link between government spending and private investment. Basar \& Temurlenk (2007) revealed that the pattern of government spending in the economy of Turkey was found to have a small negative impact on private investment for the period after 1980. Majumber (2007) noted a crowding-in effect of public borrowings on private investment in Bangladesh. In South Africa, Kollaparambil \& Nicolau (2011) noted that public spending indirectly influences private investment through the accelerator effect. Mahmoudzadeh et al. (2013) stated that for developed and developing countries the elasticity of private investment to government financing is positive in both developed and developing countries, but the enhancing effect is greater in the developed countries. The elasticity of private investment to government finances is negative in both groups, but the retarding effect is greater in the developed countries. In addition, it was observed that budget deficit has a negative and positive impact on private investment in developed and developing countries respectively.

In Pakistan between 1974 and 2010, results by Rahman, Ullah \& Jebran (2015) indicate a crowding-in effect of expenditure on agriculture, health, and transport and communication along with inflation on private investment, i.e. a crowding-out effect of community services and debt serving on private investment in the long-run and an insignificant positive and negative impact of education and defense respectively on private investment. Using panel data analysis for the economies of Bulgaria, Estonia, Latvia, Lithuania, and Slovenia, Sineviciene (2015) has revealed that the impact of increasing government expenditure on private investment is low, but the negative impact dominates, except in the case of Bulgaria, where the impact of increasing private investment on government expenditure is very different than in the other analyzed countries.

Using a fixed effect model for a panel data analysis of 5 selected West African countries (Ghana, Ivory Coast, Nigeria, Senegal and Sierra Leone), Omojolaibi et al. (2016) observed that a significant crowding-in effect of government capital expenditure and tax revenue exists while non-tax revenue showed a crowding-out effect. Recurrent expenditure and external debt also showed crowding out effects, but these were insignificant. The accelerator effect of output growth was also found to be insignificant across the countries over the time period.

Dreger \& Reimers (2016) explored the long-run relationship between public and private investment in the euro area. In contrast to previous studies, a stock-flow approach was applied to control for the different orders of integration between the stock and flow variables as well as panel econometric techniques allowing for international spillovers. Overall, the researchers noted that 
lack of public investment may have restricted private investment and GDP growth in the euro area. Their results have strong implications for the future direction of fiscal austerity programs to combat the euro area debt crisis.

Ferria \& Voia (2015) noted for the economy of Canada that government expenditure between 1870 and 2011 showed an inverted U-shaped relationship with private output. The findings revealed that while government size complements the growth of the Canadian private investment in its early stages, recent experience is more consistent with the hypothesis that increases in government size have decreased rather than increased private per capita output.

Regarding the Japanese economy, Fujii et al. (2013) submitted results that public investment confers different effects, both quantitatively and qualitatively, in individual sectors. This implies that public investment reaps different benefits in different sectors and that it can bring then unfavorable effect of resource misallocation in other sectors.

In Nigeria, Dada (2013) observed that government expenditure initiates private consumption and output in the long-run. Government expenditure on education, health, and social security crowded in private consumption, while other components such as government spending on administration, construction, agriculture, transport and communication crowded out private consumption. The short-run result revealed that the variables used do not return to equilibrium after a short-run deviation in the private consumption equation. Results by Nwosa et al. (2013) show that specifically recurrent and government final consumption expenditure crowds in private investment, while capital expenditure had a crowding out effect on private investment. Awolaja et al. (2015) suggest that government should give more priority to sectoral government investment expenditure rather than aggregate government investment expenditure. Of equal importance is the great need for government policy on investment spending to favour sectors that stimulate private sector capital formation. Apere (2014) concluded from his findings that the impact of domestic debt on private investment in Nigeria is linear and positive, and the application of the Ricardian equivalence hypothesis is not possible in the case of Nigeria. Bello et al. (2012) indicate that effective macroeconomic management is needed to cushion the adverse effect of rising inflation on private investment.

From these studies, conclusions were made which are a result of the relative approach, the period covered, and the series of variables used in the studies. This makes the present study differ in terms of method, time frame and data used. This study also argues in a different dimension then did existing studies considering the promotion of competition among private investors through government fiscal policies

\section{RESEARCH OBJECTIVE, METHODOLOGY AND DATA}

The study investigates the crowding out effect of government expenditure pattern as a fiscal policy tool on private investment. In order to formulate the model and methodology for this study, Jogenson's neoclassical theory of investment was applied.

The neoclassical theory of investment of Jogenson (1963, 1967, and 1971) is based on the optimization problem of a firm. It is argued that profit maximization of each period will yield an 
optimal capital stock result, assuming the production function to be written conventionally as;

$Y_{(t)}=\mathrm{F}\left[K_{t}, L_{t}\right]=A K^{\alpha} L^{1-\alpha}$

where $Y_{(t)}$ is firm output at the time, $K$ is capital at the time, $L_{(t)}$ is labour at the time. Assuming profit maximization, the current value of a firm, $V_{(0)}$ is written as;

$\Pi_{(t)}=P(t) Y_{(t)}-s_{(t)} I_{(t)}-w_{(t)} L_{(t)}$

$\Pi_{(t)}$ is profit at the time, $P_{(t)}$ is price of output at the time, $s_{(t)}$ is price of capital at the time, and $w_{(t)}$ represents wages at the time. To obtain the optimal capital stock $(K)$ and investment function, eqn (1) is differentiated partially, i.e.;

$\mathrm{K}^{*}=\mathrm{P}^{\alpha} \mathrm{Y} / \mathrm{c}$

Where $K^{*}$ - optimal capital output is a function of $P$ - price of output and cost of capital, (c). Therefore, investment results from the change in the optimal capital between two periods;

$\mathrm{I}=\frac{P \alpha Y}{C}-K^{*}(t-\tau)$

Contrary to the neoclassical approach, the accelerator theory, which related to Keynesian approaches, assumed fixed prices in the investment function. Therefore;

$\mathrm{I}=\alpha \mathrm{Y}$

$I$ is investment, $Y$ is output.

Omojolaibi et al. (2016) transformed the optimal capital model equation (3) to account for a panel data characteristics as;

$K_{i t}^{*}=\varphi P_{i t} Y_{i t} C_{i t}^{-\sigma}$

$\varphi$ and $\sigma$ is the distribution parameter and the constant elasticity substitution between capital stock and labour respectively. Concentrating on the net investment component, the researchers specify that investment component $\left(I_{i t}^{p i}\right)$ is equal to the change in desired capital stock.

$I_{i t}^{2}=\Delta K_{t}^{*}$

Assuming a unitary substitution between capital and labour, the model was re-stated as;

$I_{i t}=\varphi_{1} \Delta Y_{i t}+\varphi_{2} \Delta P_{i t}-\varphi_{3} \Delta C_{i t}+U_{i t}$

Omojolaibi et al. (2016) augmented equation (8) with fiscal policy variables. They disaggregated the model by following the work of Malik (2013). Fiscal policy was disaggregated in its revenue and expenditure components to account for the effect of different components of fiscal policy on private investment as well as to determine whether there is a crowding in or crowding out effect on private investment in the selected West African countries, the model was presented as;

$I_{i t}=\varphi_{1} \Delta Y_{i t}+\varphi_{2} \Delta P_{i t}+\varphi_{3} C_{i t}+\sum k \delta_{k} F P_{i t k}+\mu_{i t}$

$F P_{i t k}$ is the set of $K$ fiscal policy variables including government capital expenditure, government recurrent expenditure, direct taxes, indirect taxes, non-tax revenue and external debt.

For the purpose of the study objective, this model is modified, as we concentrate more on the effect of the government expenditure on private investment and determine if expenditure crowds out or crowds in private investment. 
$P I_{t}=\alpha+\sum_{j} \beta_{j} X_{t j}+\sum_{k} \delta_{k} F P_{t k}+\mu_{t}$

$P_{I t}$ is the private investment at the time, $X_{t j}$ is the control variables which include inflation, exchange rate and the rate of growth in the country, FP is the fiscal variables which include the capital and recurrent expenditures of government in the economy. $U$ is the error term. We therefore disaggregate the model into two to capture the components of government expenditure: capital and recurrent. The models are therefore presented below as;

$P I_{t}=\beta_{t}+C A D_{t}+C E S_{t}+C S S_{t}+C T R_{t}+X_{t}+\mu_{t}$

$P I_{t}$ implies private investment which is captured as gross capital formation as a percentage of GDP at the time, $C A D_{t}$ is the capital expenditure on administration at the time, $C E S_{t}$ is the capital expenditure on economic services at the time, CSS $S_{t}$ is the capital expenditure on social services at the time and $C T R_{t}$ is the capital expenditure on transfer at the time. $X_{t}$ includes the control macro-economic variables such as inflation rate, and lending rate at the time, while $\mu_{t}$ is the error term at the time.

The model for recurrent expenditure is presented below as;

$P I_{t}=\beta_{t}+R A D_{t}+R E S_{t}+R S S_{t}+R T R_{t}+X_{t}+\mu_{t}$

$\mathrm{PI}_{t}$ implies private investment which is captured as gross fixed capital formation as a percentage of GDP at the time, $R A D_{t}$ is the government recurrent expenditure on administration at the time, $R E S_{t}$ is the government recurrent expenditure on economic services at the time, $R S S_{t}$ is the government recurrent expenditure on social services at tie and $R T R_{t}$ is the government recurrent expenditure on transfer at the time. $X_{t}$ include the control variables such as inflation rate and lending rate at the time, while $\mu_{t}$ the error term at the time.

Using equation 11 and 12, we specify the ARDL model for this study as;

$\mathrm{PI}_{t}=c_{0}+\sum_{q=1}^{p} \beta_{1} \mathrm{PI}_{t-i}+\sum_{q=0}^{j_{1}} \beta_{2} \operatorname{InCAD} D_{t-i}+\sum_{q=0}^{j_{2}} \beta_{3} \operatorname{InCES} S_{t-i}+\sum_{q=0}^{j_{3}} \beta_{4} \operatorname{CSS}_{t-i}+$ $\sum_{q=0}^{j_{4}} \beta_{5-} \operatorname{InCTR}_{t-i}+\sum_{q=0}^{j_{5}} \beta_{6-} X_{t-i}+\varepsilon_{t}$

Equation 13 is the ARDL long run model for capital expenditure components ADC, ESC, SSC, TRC and macro-economic indicators $\mathrm{X}$ - lending rate and inflation rate.

Equation 14 presents the short-run model of the capital expenditure components and the macroeconomic indicators $\mathrm{X}$ - lending rate and inflation rate.

$\Delta P I_{t}=\vartheta+\sum_{q=1}^{p} \rho_{1} \Delta I n \mathrm{PI}_{t-i}+\sum_{q=1}^{j_{1}} \rho_{2} \Delta C A D_{t-j}+\sum_{q=1}^{j_{2}} \rho_{3} \operatorname{CES}_{t-j}+\sum_{q=1}^{j_{3}} \rho_{4} \Delta C S S_{t-j}+$

$\sum_{q=1}^{j_{4}} \rho_{5} \Delta \operatorname{InCTR}_{t-j}+\sum_{q=1}^{j_{5}} \rho_{6} \Delta X_{t-j}+\delta e c m_{i-1}+\varepsilon_{t}$

Equation 15 is the ARDL long run model for the recurrent expenditure components ADC, ESC, SSC, TRC and macro-economic indicators $\mathrm{X}$ - lending rate and inflation rate.

$\mathrm{PI}_{t}=c_{0}+\sum_{q=1}^{p} \beta_{1} \mathrm{PI}_{t-i}+\sum_{q=0}^{j_{1}} \beta_{2} \operatorname{InRAD}_{t-i}+\sum_{q=0}^{j_{2}} \beta_{3} \operatorname{InRES}_{t-i}+\sum_{q=0}^{j_{3}} \beta_{4} \mathrm{RSS}_{t-i}+$ $\sum_{q=0}^{j_{4}} \beta_{5_{-}} \operatorname{InRTR}_{t-i}+\sum_{q=0}^{j_{5}} \beta_{6-} X_{t-i}+\varepsilon_{t}$

Equation 16 presents the short-run model of capital expenditure components and the macroeconomic indicators $\mathrm{X}$ - lending rate and inflation rate.

$\Delta P I_{t}=\vartheta+\sum_{q=1}^{p} \rho_{1} \Delta I n \mathrm{PI}_{t-i}+\sum_{q=1}^{j_{1}} \rho_{2} \Delta R A D_{t-j}+\sum_{q=1}^{j_{2}} \rho_{3} \mathrm{RES}_{t-j}+\sum_{q=1}^{j_{3}} \rho_{4} \Delta R S S_{t-j}+$ $\sum_{q=1}^{j_{4}} \rho_{5} \Delta \operatorname{InRTR}_{t-j}+\sum_{q=1}^{j_{5}} \rho_{6} \Delta X_{t-j}+\delta e c m_{i-1}+\varepsilon_{t}$ 
From equations $13,14,15$ and $16, \beta_{1}-\beta_{6}$ represent long-run multipliers of the variables. While, $Q_{1}-\varrho_{5}$ reprsent the short-run multipliers of the variables, while the long-run and short-run intercept of the models are $c_{0}$ and $\vartheta_{0}$ and $j_{1}-j_{5}$ are the optimal lags length of each of the variables as revealed in the results.

The data used for the study include private investment proxy as gross fixed capital formation, recurrent and capital expenditure on: administration, economic services, social services, transfers; Inflation rate and Lending rate. Gross fixed capital was used as a proxy for private investment as used in Jalloh (2002), Majumber (2007), Sineviciene et al. (2012) and Omojolaibi et al. (2016) study. It explains the contribution of private investment to the growth of an economy. The aforementioned conditioning variables were chosen because of their strong theoretical and empirically proven relationship with private investment (Omojolaibi et al., 2016). In line with previous studies such as Bello et al., (2012), Nwosa et al. (2013), Dada (2013), and Omojolaibi et al., (2016), fiscal policy is disaggregated to capture the crowding in/out effect on private investment in Nigeria within the time period under study. The data used for the study are secondary in nature and are sourced from the Central Bank of Nigeria (CBN) Statistical Bulletin (2015) and World Development Indicators (WDI) (2015).

\section{RESULTS AND DISCUSSION}

The analysis of the study is presented separately.

\subsection{Descriptive Statistics Analysis}

The descriptive statistics is used to measure data variability and the spread of the distribution of the set of data. This facilitated the decision on the normality of the variables employed in the study and also helped to identify the variables that needed to be transformed into the natural $\log$.

Skewness was used to measure the asymmetry of the distribution around its mean. For the capital expenditure model, it was revealed that all the variables show a long tail to the right. This implies that they are positively skewed to the right, by which h limits the estimation of the model to take place in linear form. Kurtosis revealed that gross fixed capital formation, lending rate, inflation rate, and capital expenditure on transfer are peaked to normal, which implies that they are leptokurtic, as they have values greater than 3. Capital expenditure on administration, economic services, and social services are flat relative to normal, which implies that they are platykurtic, as they have values lower than 3. The Jaque-Bera statistics reveal that the variables are not all normally distributed, as they show a probability value lower than $10 \%$ level of significance except for capital expenditure on economic service, which is greater than 10\% (see Table 1).

For the recurrent expenditure model, it was revealed that recurrent expenditure on administration, transfer, economic services and social services show a long tail to the left, which implies that they are negatively skewed in that direction. The need to transform the variables by taking a natural $\log$ of the variables is present. Gross fixed capital formation, lending rate and inflation rate show a long tail to the right, which implies they are positively skewed and there is no need to take a natural log of the variable (see Table 2). Further, for the capital and recurrent expenditure 
model, it was revealed that all the variables display a mean lying between their minimum and maximum levels. This implies that they fall within the expected changes over the period under study. It can be also inferred that all the variables are well-behaved within the period (see Table 1 and 2).

Tab. 1 - Descriptive Statistics for Capital Expenditure Model. Source: author computation

\begin{tabular}{|l|l|l|l|l|l|l|l|}
\hline & GCF & INFLR & LNDR & CTR & CAD & CES & CSS \\
\hline Mean & 12.72 & 19.71 & 17.81 & 53.40 & 90.87 & 172.70 & 45.08 \\
\hline Maximum & 35.22 & 72.84 & 31.65 & 265.90 & 291.66 & 506.01 & 154.71 \\
\hline Minimum & 5.46 & 5.38 & 8.92 & 0.01 & 0.26 & 0.66 & 0.24 \\
\hline Std. Dev. & 6.41 & 17.94 & 5.04 & 69.24 & 105.67 & 175.15 & 54.57 \\
\hline Skewness & 2.01 & 1.63 & 0.18 & 1.69 & 0.75 & 0.54 & 0.97 \\
\hline Kurtosis & 7.44 & 4.37 & 3.43 & 4.86 & 1.93 & 1.91 & 2.47 \\
\hline $\begin{array}{l}\text { Jarque- } \\
\text { Bera }\end{array}$ & 52.27 & 18.17 & 0.44 & 21.13 & 4.96 & 3.41 & 5.85 \\
\hline Prob & 0.00 & 0.00 & 0.80 & 0.00 & 0.08 & 0.18 & 0.05 \\
\hline Obs & 35 & 35 & 35 & 34 & 35 & 35 & 35 \\
\hline
\end{tabular}

Tab. 2 - Descriptive Statistics for Recurrent Expenditure Model. Source: author's computation

\begin{tabular}{|l|l|l|l|l|l|l|l|}
\hline & GCF & INFLR & LNDR & LRAD & LRES & LRSS & LRTR \\
\hline Mean & 12.712 & 19.72 & 17.81 & 3.99 & 2.52 & 3.11 & 4.58 \\
\hline Maximum & 35.22 & 72.84 & 31.65 & 7.14 & 6.33 & 6.74 & 7.33 \\
\hline Minimum & 5.46 & 5.38 & 8.92 & -0.11 & -1.76 & -1.24 & 1.22 \\
\hline Std. Dev. & 6.42 & 17.94 & 5.04 & 2.53 & 2.69 & 2.79 & 2.04 \\
\hline Skewness & 2.01 & 1.63 & 0.18 & -0.29 & -0.21 & -0.29 & -0.28 \\
\hline Kurtosis & 7.44 & 4.37 & 3.43 & 1.65 & 1.66 & 1.70 & 1.73 \\
\hline $\begin{array}{l}\text { Jarque- } \\
\text { Bera }\end{array}$ & 52.27 & 18.17 & 0.44 & 3.15 & 2.88 & 2.93 & 2.81 \\
\hline Probability & 0.00 & 0.000 & 0.80 & 0.21 & 0.24 & 0.23144 & 0.25 \\
\hline $\begin{array}{l}\text { Observa- } \\
\text { tions }\end{array}$ & 35 & 35 & 35 & 35 & 35 & 35 & 35 \\
\hline
\end{tabular}

\subsection{Correlation Matrix}

The correlation test is used to test for presence of multicollinearity among the variables to avoid a contradictory result. For this study, the correlation result will be validated based on the argumant by Iyoha (2004) that multicollinearity among variables occurred when the result of the correlation coefficient is greater than 0.95. Following the estimated models of the study, the results reveal that the independent variables had a weak negative correlation with the dependent variable. This implies that the variables are independent of each other and free of the multicollinearity problem (see Table 3 and 4). 
Tab. 3 - Correlation Matrix for Capital Expenditure. Source: author's computation

\begin{tabular}{|l|l|l|l|l|l|l|l|}
\hline & GCF & INFLR & LNDR & TRC & ADC & ESC & SSC \\
\hline GCF & 1 & -0.093 & -0.52 & -0.09 & -0.16 & -0.26 & -0.15 \\
\hline INFLR & -0.09 & 1 & 0.40 & -0.20 & -0.41 & -0.43 & -0.38 \\
\hline LNDR & -0.52 & 0.40 & 1 & 0.11 & -0.02 & 0.04 & -0.01 \\
\hline CTR & -0.09 & -0.20 & 0.11 & 1 & 0.57 & 0.65 & 0.52 \\
\hline CAD & -0.16 & -0.41 & -0.02 & 0.57 & 1 & 0.94 & 0.97 \\
\hline CES & -0.26 & -0.43 & 0.04 & 0.65 & 0.94 & 1 & 0.92 \\
\hline CSS & -0.15 & -0.38 & -0.01 & 0.52 & 0.97 & 0.92 & 1 \\
\hline
\end{tabular}

Tab. 4 - Correlation Matrix for Recurrent Expenditure. Source: author's computation

\begin{tabular}{|l|l|l|l|l|l|l|l|}
\hline & GCF & INFLR & LNDR & LADR & $\begin{array}{l}\text { LO- } \\
\text { GESR }\end{array}$ & LOGSSR & LOGTRR \\
\hline GCF & 1 & -0.081 & -0.54 & -0.48 & -0.45 & -0.46 & -0.47 \\
\hline INFLR & -0.08 & 1 & 0.37 & -0.27 & -0.27 & -0.25 & -0.25 \\
\hline LNDR & -0.54 & 0.37 & 1 & 0.36 & 0.36 & 0.36 & 0.38 \\
\hline LRAD & -0.48 & -0.27 & 0.357 & 1 & 0.99 & 0.99 & 0.99 \\
\hline RES & -0.45 & -0.27 & 0.36 & 0.99 & 1 & 0.98 & 0.98 \\
\hline LRSS & -0.46 & -0.25 & 0.36 & 0.99 & 0.98 & 1 & 0.98 \\
\hline LRTR & -0.47 & -0.25 & 0.38 & 0.99 & 0.98 & 0.98 & 1 \\
\hline
\end{tabular}

\subsection{Selection of optimal Lag}

In order to determine the lag length, the Schwarz Information Criterion (SIC) was need. Following the SIC, we used the optimal lag of 1 for the ARDL estimates, as can be seen here in Table 5.

Tab. 5 - Optimal lag selection for CE and RE models. Source: author's computation

\begin{tabular}{|l|l|l|}
\hline & CE Model & RE Model \\
\hline Lag & SIC & SIC \\
\hline 0 & 61.8531 & 26.4107 \\
\hline 1 & $60.55725^{*}$ & $22.41707^{*}$ \\
\hline
\end{tabular}

\subsection{Pre-Estimation Diagnostic Test}

It is also important to discuss the preliminary diagnostic tests that are generally used in crosssectional data analysis, namely the unit root test and co-integration test, before the empirical results are presented.

\subsubsection{Unit root Result}

The unit root test is used to test for the presence of stationarity among variables. It helps to 
determine if the variables are mean reverting, that is if they are predictable. The results are validated at their order of integration. The order of integration explains the number of times the series is differenced to achieve stationarity. All the variables are expected to be stationary at $\mathrm{I}(0)$ or at most I(1). From this result, it was revealed that the variables are stationary at these levels and at the first difference, which implies a problem of unit root presence among the variables (see Table 6).

Tab. 6 - Unit root Test Results. Source: author's computation

\begin{tabular}{|l|l|l|l|l|l|}
\hline \multirow{2}{*}{ Variable } & \multicolumn{2}{|l|}{ At Level } & \multicolumn{2}{l|}{ 1st Difference } & $\begin{array}{l}\text { Order of } \\
\text { Integration }\end{array}$ \\
\hline & None & $\begin{array}{l}\text { Trend \& } \\
\text { Intercept }\end{array}$ & None & $\begin{array}{l}\text { Trend \& } \\
\text { Intercept }\end{array}$ & \\
\hline GCF & $-3.02^{* * *}$ & $-3.62^{* * *}$ & $-3.64 * * *$ & $-4.08^{* * *}$ & $\mathrm{I}(0)$ \\
\hline INFLR & -1.85 & -2.93 & $-5.44 * * *$ & $-5.29 * * *$ & $\mathrm{I}(1)$ \\
\hline LNDR & -0.19 & -2.14 & $-6.48^{* * *}$ & $-6.53^{* * *}$ & $\mathrm{I}(1)$ \\
\hline CAD & 0.55 & -1.99 & $-5.83^{* * *}$ & $-6.07 * * *$ & $\mathrm{I}(1)$ \\
\hline CES & -0.41 & -3.40 & $-7.50^{* * *}$ & $-7.45^{* * *}$ & $\mathrm{I}(1)$ \\
\hline CSS & -0.63 & -2.49 & $-6.67 * * *$ & $-6.53^{* * *}$ & $\mathrm{I}(1)$ \\
\hline CTR & -1.72 & -4.35 & $-8.45^{* * *}$ & $-8.27 * * *$ & $\mathrm{I}(1)$ \\
\hline RAD & 2.09 & -1.81 & $-5.51^{* * *}$ & $-7.86^{* * *}$ & $\mathrm{I}(1)$ \\
\hline RES & 0.65 & -2.56 & $-6.08^{* * *}$ & $-7.09^{* * *}$ & $\mathrm{I}(1)$ \\
\hline RSS & 0.96 & -3.45 & $-6.48^{* * *}$ & $-7.58^{* * *}$ & $\mathrm{I}(1)$ \\
\hline RTR & 2.76 & -2.11 & $-5.38^{* * *}$ & $-7.88^{* * *}$ & $\mathrm{I}(1)$ \\
\hline
\end{tabular}

$* * *, * *, *$ implies the significance level at $1 \%, 5 \%$, and $10 \%$ respectively.

\subsection{Bounds test for the Models}

For the two models, the F-statistics determined that the greater value was found to be greater than the critical values of $\mathrm{I}(0)$ (Lower bound) and I(1) (Upper bound) bounds. This implies that there is a co-integration among the variables (see Table 7 and 8 ).

Tab. 7 - Bounds test for Capital Expenditure Model. Source: author's computation

\begin{tabular}{|l|l|l|}
\hline Model for Estimation & F-Statistics & Lower-Upper bound at 5\% \\
\hline CAD/CES/CSS/CTR/INFLR/LNDR & $5.19 *$ & $2.87-4$ \\
\hline
\end{tabular}

* implies cointegrating factors at $5 \%$ level of significance.

Tab. 8 - Bounds test for Recurrent Expenditure Model. Source: author's computation

\begin{tabular}{|l|l|l|}
\hline Model for Estimation & F-Statistics & Lower-Upper bound at 5\% \\
\hline RAD/RES/RSS/RTR/INFLR/LNDR & $6.17^{*}$ & $2.87-3.6$ \\
\hline
\end{tabular}

* implies cointegrating factors at 5\% level of significance. 


\subsection{Short run Coefficient Result}

The results show that capital expenditure had a negative and insignificant impact on private investment in the short-run, which implies that the shocks in private investment in the previous year in Nigeria were corrected by $69 \%$ annually by capital expenditure, while recurrent expenditure had a positive and significant impact on private investment in the short-run, which implies that approximately $41 \%$ of disequilibrium in private investment in the previous period was corrected by recurrent expenditure (see Table 9 and 4.10).

Tab. 9 - ECM for Capital Expenditure. Source: author's computation

\begin{tabular}{|l|l|l|l|l|}
\hline & Coefficient & Std Error & t-statistics & Prob \\
\hline ECM(-1) & -0.690091 & 0.592837 & -1.164048 & 0.2569 \\
\hline
\end{tabular}

Tab. 10 - ECM for Recurrent Expenditure. Source: author's computation

\begin{tabular}{|l|l|l|l|l|}
\hline & Coefficient & Std Error & t-statistics & Prob \\
\hline ECM $(-1)$ & 0.408228 & 0.153289 & 2.663136 & 0.0136 \\
\hline
\end{tabular}

\subsection{Long-run Coefficient Results}

These results are presented based on the model on the disaggregation of government expenditure: Capital and Recurrent expenditure.

Tab. 11 - Long-run Coefficient Result for Capital Expenditure Model. Source: author's computation

\begin{tabular}{|l|l|l|l|l|l|l|}
\hline & CAD & CES & CSS & CTR & INFLR & LNDR \\
\hline Coefficient & 0.10 & -0.02 & -0.01 & 0.04 & -0.06 & 0.38 \\
\hline t-stat & $(-3.62)$ & $(-1.43)$ & $(-0.23)$ & -2.41 & $(-1.75)$ & $(-2.23)$ \\
\hline Prob & 0.002 & 0.173 & 0.818 & 0.029 & 0.099 & 0.040 \\
\hline
\end{tabular}

From this result, it was revealed that capital expenditure on economic services and social services had a negative and insignificant impact on private investment in the long-run, whereas inflation rate also had a negative but significant impact on private investment at a $10 \%$ level of significance. Capital expenditure on administration, transfer and lending rates showed a positive and significant impact on private investment at a 5\% level of significance. Table 11 presents the long run coefficient result for recurrent expenditure (see Table 11 above). 
Tab. 12 - Long run Coefficient Result for Recurrent Expenditure Model. Source: Author's Computation

\begin{tabular}{|l|l|l|l|l|l|l|}
\hline & InRAD & InRES & InRSS & InRTR & INFLR & LNDR \\
\hline Coefficient & -4.24 & -3.72 & 2.83 & 3.19 & -0.05 & 0.05 \\
\hline t-stat & $(-1.19)$ & $(-3.25)$ & -0.99 & -1.36 & $(-1.52)$ & -0.23 \\
\hline Prob & 0.257 & 0.007 & 0.341 & 0.199 & 0.153 & 0.820 \\
\hline
\end{tabular}

Based on the recurrent expenditure results, it was revealed that recurrent expenditure had a negative and insignificant impact on private investment on administration, while recurrent expenditure on economic services had a negative and significant impact on private investment. It was also revealed that recurrent expenditure on social services, transfer, as well as the inflation rate had a positive and insignificant on private investment (see Table 12 above).

\section{DISCUSSION}

This result was found to be in conformity with some previous studies and went against the results of others. In line with Bom (2017), the result divulges that the complex dynamics of private capital formation, as well as its sensitivity to key parameters and financing mode, may help explain the mixed empirical evidence on the private-public investment relationship. Based on this interpretation, the effect of public spending depends on the type of expenditure. This study diverges from neoclassical theory that government expenditure crowds out private investment. Keynesian approaches project that government expenditure strictly crowds in private investment, a result which is shown in the work of some previous studies in the developing countries such as Omojolaibi (2016), i.e. that capital and recurrent expenditure as a whole crowd in private investment. In conformity with the work of Mohammad et al. (2012), however, the actual impact of government spending on private sector investment varies depending on the type of government expenditure under consideration. Moreover, having a sound expenditure management and allocation policy together with other fiscal policy is imperative in determining private investment in the developing countries such as Nigeria. Also, in agreement with Fujii et al. (2013), public investment has differential effects in each industry, such as the productive externality of public capital, which consists of accumulating public investment and differences in wealth or demand shock. They explain that the components of government expenditure display various impacts on the investments in a country, a result which we also found under the same conditions for Nigeria. From the coefficients of the expenditure results, the study also agrees with the work of Nwosa (2013) that the pattern of spending of the government largely determines the functioning of private investment in the economy. This is because one of the major determinants of growth and development is the expenditure pattern of the government of an economy, which private investors consider before investing in the economy in order to avoid loss. In support with the findings of Apere (2014), the study also argued that the Ricardian equivalence theory does not hold in the case of Nigeria, as government expenditure is found to have a great impact on private investment. In support of the Keynesian view, lending rate positively reacts in a low way to private investment and is not significant. This implies that government expenditure policies in the Nigerian economy greatly influence competiveness among private investors in the economy. 


\section{CONCLUSION}

The study investigates the disaggregated effect of government expenditure on private investment in Nigeria from 1981 to 2015 using the ARDL approach. It was observed from the findings that the effect of public expenditure on private investment varies with regard to the components of the expenditure. We therefore conclude that a major determinant of improved private investment in Nigeria is the pattern of government expenditure.

Based on these findings, we recommended that an expenditure plan should be designed in such a way that macro-economic variables such as inflation rate and lending rate are taken into consideration as a factor that determines the interest of private investors in the economy, since as more money is pumped into the economy, prices of goods and services tend to increase as well as savings, which may lead to an increase in the cost of capital as well as discourage investors from investing in the economy, as the cost of capital is high. Therefore, policies toward determining the appropriate amount of funding to release in the economy should be considered in terms of facilitating and increasing private investment.

\section{References}

1. Apere, T. O. (2014). The Impact of Public Debt on Private Investment in Nigeria: Evidence from a Nonlinear Model. International Journal of Research in Social Sciences, 4 (2), 130-138.

2. Awolaja, G., Oluwalaiye O. B., Lawal, E. (2015). The Effect of Sectorial Public Investment Expenditure on Private Investment in Nigeria: An Error Correction Analysis. European Journal of Business and Social Sciences, 4 (4), 87-104.

3. Basar, S., \& Temurlenk, M. S. (2007). Investigating Crowding-Out Effect of Government Spending For Turkey: A Structural VAR Approach. İktisadi ve İdari Bilimler Dergisi, 21 (2), 96-104.

4. Bello, M. Z., Nagwari, A. B., \& Saulawa, M. A. (2012). Crowding In Or Crowding Out? Government Spending and Private Investment: The Case of Nigeria. European Scientific Journal, 8 (28), 9-22. http://dx.doi.org/10.19044/esj.2012.v8n28p\%25p

5. Bom, P. R. D. (2017). Factor-Biased Public Capital and Private Capital Crowding Out. Journal of Macroeconomics, 52 (2017), 100-117. http://dx.doi.org/10.1016/j.jmacro.2017.03.002

6. Dada, M. A. (2013). Composition Effects of Government Expenditure on Private Consumption and Output Growth in Nigeria: a Single-Equation Error Correction Modeling. Romanian Journal of Fiscal Policy, 42 (7), 18-34. http://hdl.handle.net/10419/107949

7. Dreger, C., \& Reimers, H. E. (2016). Does public investment stimulate private investment? Evidence for the euro area. Economic Modelling, 58, 154-158. https://doi.org/10.1016/ j.econmod.2016.05.028

8. Ferris, J. S., \& Voia, M. C. (2015). The effect of federal government size on private economic performance in Canada: 1870-2011. Economic Modelling, 49, 172-185. https://doi. org/10.1016/j.econmod.2015.04.006

9. Fujii, T., Hiraga, K., \& Kozuka, M. (2013). Effects of public investment on sectoral private investment: A factor augmented VAR approach. Journal of the Japanese and International Economies, 27, 35-47. https://doi.org/10.1016/j.jiie.2012.11.003 
10. Haliu, F. (2015). Crowding in or Crowding out? Government Expenditure and Private Investment in Ethiopia (1980-2012). Journal of Economics and Sustainable Development, 6 (9), $59-66$.

11. Ho, Thug-W. (2001). The Government Spending and Private Consumption: A Panel Cointegration Analysis. International Review of Economics and Finance, 10, 95-108. https://doi. org/10.1016/S1059-0560(00)00073-3

12. Jalloh, M. (2002). An Analysis of the Macroeconomic Determinants of Private Investment in Sierra Leone. Addis Ababa University School of Graduate Studies, 1, 78-81.

13. Jorgenson, D. W. (1963). Capital Theory and Investment Behaviour. American Economic Review, 53 (2), 247-259. https://www.jstor.org/stable/1823868

14. Jorgensen, D. (1967). The Theory of Investment Behaviors, in Determinants of Investment. National Bureau of Economic Research, 129-155. http://www.nber.org/chapters/c1235

15. Jorgenson, D. W. (1971). Econometric studies of investment behaviour: A Survey. Journal of Economic Literature, 1111-1147. https://www.jstor.org/stable/2721137

16. Kollamparambil, U., \& Nicolaou, M. (2011). Nature and association of public and private investment: Public policy implications for South Africa. Journal of Economics and International Finance, 3 (2), 98-108.

17. Mahoudzadeh, M. Sadeghi, S., \& Sadeghi S. (2013). Fiscal Spending and Crowding out Effect: A Comparison between Developed and Developing Countries. Institutions and Economies, 5 (1), 31-40. http://ajba.um.edu.my/index.php/ijie/article/view/4873

18. Majumder, A. (2007). Does Public Borrowing Crowd-out Private Investment? The Bangladesh Evidence. Policy Analysis Unit (PAU). Working Paper Series: WP 0708. 2-26.

19. Malik, A. (2013). Private Investment and Fiscal Policy in Pakistan. Journal of Economic Development, 38 (1), 89-91.

20. Muhammad, Z. B., Aminu, B. N., \& Mubarak, A. S. (2012). Crowding In Or Crowding Out? Government Spending and Private Investment: The Case of Nigeria. European Scientific Journal (ESJ), 8 (28). http://dx.doi.org/10.19044/esj.2012.v8n28p\%25p

21. Narayan, P. K., (2004). Do public investments crowd out private investments? Fresh evidence from Fiji. Journal of Policy Modeling, 26, 747-753. https://doi.org/10.1016/ j.jpolmod.2004.06.002

22. Nwosa P. I., Adebiyi O. O., \& Adedeji A.O. (2013): An Analysis of the Relationship between Public Spending Components and Private Investments in Nigeria. Journal of Finance \& Economics, 1 (2), 14-27.

23. Omojolaibi, J. A., Okenesi, T. P., \& Mesagan, E. P. (2016). Fiscal Policy and Private Investment in Selected West African Countries. CBN Journal of Applied Statistics, 7(1b), 277-309.

24. Rahman, M., Ullah, I., \& Jebran, K. (2015). Effects of Government Expenditure on Private Investment: Evidence from Pakistan. Journal of Basic and Applied Scientific Research, 5 (2), $14-23$. 
25. Sineviciene, L., \& Railiene, G. (2015). The Nexus between Government Size, Tax Burden and Private Investment. Procedia - Social and Behavioral Sciences, 213, 485-490. https://doi. org/10.1016/j.sbspro.2015.11.438

26. Sineviciene, L., \& Vasiliauskaite, A. (2012). Fiscal Policy Interaction with Private Investment: The Case of the Baltic States. Inqinerine Ekonomika-Engineering Economics, 23 (3), 233-241. http://dx.doi.org/10.5755/j01.ee.23.3.1934

27. Sinevičienè, L. (2015). Testing the Relationship between Government Expenditure and Private Investment: The Case of Small Open Economies. Journal of Economics, Business and Management, 3 (6), 628-632. http://dx.doi.org/10.7763/JOEBM.2015.V3.256

\section{Contact information}

Olawunmi Omitogun, PhD.

Olabisi Onabanjo University, Ogun State, Nigeria

Faculty of Social Sciences

Department of Economics

Nigeria

Email:omitogun.olawunmi@oonagoiwoye.edu.ng 